\title{
The Impacts Of The War On Terrorism On Maritime Shipping
}

Arthur P. James, (Email: jamesa@tamug.tamu.edu), Texas A\&M University, Galveston H.G. Van Dell, (Email: hg@ vandell.net), State University of New York Maritime College

\begin{abstract}
The terrorist acts that destroyed the World Trade Center and part of the Pentagon have, of course, changed much of the world in many ways since September 2001. Among those effects has been a pronounced and noticeable shift in airport and aircraft security. Much less noticeable to most Americans has been the impact of added security and changed priorities on maritime transportation systems. But maritime security actually has a far greater impact on commerce than does air security because most cargo moves worldwide via commercial ocean-going vessels. Security requirements and wartime priorities are compelling the world's governments to more closely monitor and inspect all vessels and cargo entering their nation's ports. The US Coast Guard's inspections are forcing tremendous delays upon entering vessels. The consequences of losing millions of dollars daily both for shipping companies and cargo interests create severe economic and logistical problems that impact all transportation modes. The new US embargo on 24 small countries may force them into bankruptcy unless they comply with US requests to end terrorism. These countries depend on exports and imports for a large portion of their GDP, which will be dramatically reduced unless they join the war against terrorism. This paper examines five impacts on the US and world shipping industry caused by the war on terrorism--those on: 1) vessel and port security; 2) transportation- and trade-related communications; 3) trade levels; 4) marine insurance; and 5) maritime and related freight rates. Then the authors draw some conclusions regarding possibilities of reflagging of ships and effects on the status of the US merchant marine industry.
\end{abstract}

\section{Introduction}

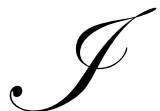

$\mathrm{n}$ the aftermath of the terrorist attacks that took place on September 11, 2001, the world is in many ways, of course, a different place. The defeat of worldwide terrorism is now foremost on the minds of most Americans and, indeed, on those of most of the free world's peoples. Terrorism poses a distinct threat to the safety and security of the world, and reduces the economic well being of all but perhaps a few of the world's citizens. The manner by which the terrorists of September 11 carried out their act has had broad repercussions on travel, since common, everyday passenger aircraft were the chosen "weapons of mass destruction" of that day. The effect that the terrorists have had on airline passengers and airport security has been the most obvious commercial impact of the $9 / 11$ events. Heightened airport security has resulted in mandatory earlier arrival at the airport, stricter--and longer--security checks, potential for terminal evacuations, longer tarmac waiting time, and other "speed offsets" that make our total trip time considerably longer and more inconvenient now when we travel by air. That story has been replayed in all the news media countless times since $9 / 11$, and so should be familiar by now to everyone who might even think about flying.

Of course, worries about air travel safety are important to anyone who flies because the terrorists demonstrated to all of us the potential loss of innocent life that could swiftly occur when an aircraft is hijacked and flown into an occupied skyscraper like the World Trade Center. However, the real threat to worldwide transportation is mostly not an aircraft-related problem nor, in fact, is it primarily a commercial passenger-related

Readers with comments or questions are encouraged to contact the authors via email. one (although passengers are still a concern, of course). In fact, the far greater terrorist threat to worldwide transpor- 
tation is that posed by potential attacks on maritime commerce and, in particular, on maritime freight. While the prospects of terrorism on the world's marine ports and maritime vessels may seem of little significance to the average citizen, they are far from insignificant when one recognizes the part that maritime commerce plays in worldwide commerce. The fact is, most of the international trade community is not well-informed regarding US or other nations' security strategy for cargo or the maritime traffic system (MTS). We would never understate the importance of the destruction and the loss of human life brought about by the WTC and Pentagon attacks. However, the real terrorist threat for most of the world is likely to be a "weapon of mass disruption," such as an attack on a major world port or on a vessel within the vicinity of a port, in order to disrupt commerce. Airfreight accounts for only about 0.4 percent (in tonmiles) of US intercity freight carriage by modal split, while domestic intercity waterborne cargo accounts for over 27 percent of total domestic freight. Internationally, 95 percent of freight moving between countries does so by water. If a terrorist attack occurs somewhere in a maritime transportation system, it is likely to have devastating effects on international trade. The flow of trade would likely come to a virtual standstill for some long - and inestimable - time period. The effects, of course, would be particularly severe if the event were to occur in the United States because we are the world's largest trading nation, by absolute volume of trade.

Some brief statistics regarding the US MTS demonstrate its importance. It

- $\quad$ Moves over 2 billion tons of cargo (both foreign and domestic) annually;

- $\quad$ Contributes about $\$ 750$ billion annually to US Gross Domestic Product-about $7.25 \%$ of total US goods and services output;

- $\quad$ Generates more than 13 million US jobs;

- $\quad$ Ships 9 million barrels of imported crude oil and other petroleum products per day; $2 / 3$ of all petroleum products travel by water;

- $\quad$ Ships $25 \%$ of all hazardous materials;

- $\quad$ Moves $95 \%$ of all US overseas trade by tonnage;

- $\quad$ Exports $14 \%$ of the world's ocean borne trade;

- Transports 134 million passengers by ferryboat annually. ${ }^{1}$

As striking as these numbers may seem, no US port is near the world's leaders in overall cargo tonnage. Rotterdam, in the Netherlands, is the world's largest port based on throughput tonnage, and the rest of the top five are all Asian ports, in Mainland China, Hong Kong, Taiwan, and Singapore. In containerized freight, however, the fastest growing segment of world trade, and the area where many of the significant terrorist threats are expected, the top four ports are in Asia (95\% of Hong Kong's tonnage is containerized), with Rotterdam fifth. In general, all of these countries depend much more heavily on maritime trade as a portion of their GDP that does the US. Therefore, port and vessel security is not merely a US problem; rather it is one of significant international interest. The big distinction, of course, is that the current terrorism threat appears to be against Western nations and their ideals, so ports such as Rotterdam, Antwerp, New York, Vancouver, Los Angeles/Long Beach, Charleston, and Houston are the more likely targets of terrorism.

${ }^{1}$ US Coast Guard Office of Waterways Management Policy and Planning (G-MWP), MTS: Marine Transportation System information pamphlet. 


\begin{tabular}{|l||c|c||c||}
\hline \multicolumn{4}{|c|}{$\begin{array}{l}\text { Top Ten Container Ports of the World } \\
\text { (In thousands of TEUs) }\end{array}$} \\
\hline \hline Hong Kong & 1995 & 1999 & $\mathbf{2 0 0 0}$ \\
\hline \hline Singapore & 12,550 & 16,211 & 18,098 \\
\hline \hline Pusan (S. Korea) & 4,846 & 15,945 & 17,040 \\
\hline \hline Kaoshiung (Taiwan) & 5,053 & 6,985 & 7,426 \\
\hline \hline Rotterdam & 4,787 & 6,342 & 6,275 \\
\hline \hline Shanghai & 1,527 & 4,210 & 5,613 \\
\hline \hline Los Angeles & 2,555 & 3,829 & 4,879 \\
\hline \hline Long Beach & 2,844 & 4,408 & 4,601 \\
\hline \hline Hamburg & 2,890 & 3,738 & 4,250 \\
\hline \hline Antwerp & 2,329 & 3,614 & 4,100 \\
\hline \hline Source: Hong Kong Port \& Maritime Board (data for 2000, etc.) & & 7,540 \\
\hline \hline
\end{tabular}

Long before 9/11, Southeast Asian maritime trade has had, and continues to have, a problem related to terrorism - that of piracy on the high seas. The International Maritime Piracy Bureau's latest report showed that, of 192 recently reported worldwide acts of piracy, 92 were in Southeast Asia, primarily in the Strait of Malacca (near Singapore), around Hong Kong, and near the Philippines. Of course, the Philippines are currently on the list of nations harboring Islamic militant groups. Shipowners and cargo interests in these geographic areas must certainly be aware of vessel security efforts, since it seems that it is vessels rather than ports that are of primary concern in that part of the world.

This paper takes a brief look at several effects that the terrorist acts of 9/11/01 have had on the world shipping market. Section I looks at the US response to vessel and port security, with generalizations to the rest of the world. Section II briefly examines some of the effects of terrorist disruption of the communication system surrounding the maritime industry. Section III presents evidence of the disruption of world trade. Section IV looks at the resulting effects on freight rates, shipping revenues, and profits. Section V discusses the important issue of marine insurance. Finally, Section VI examines possible effects that all of the above might have on the future of the US maritime industry, and how the US will treat shipping companies, shipowners, and mariners from the rest of the world.

\section{Vessel and Port Security}

For the past four years, the US Coast Guard has sponsored an annual National Harbor Safety Committee Conference. Harbor Safety Committees are local organizations at each US port whose responsibility it is to ensure the safety of vessels and security of port infrastructure. At last spring's Third annual meeting, there was little emphasis on terrorism as a major safety and security concern. Drug and other contraband smuggling, illegal immigration, and vessel traffic control problems that might cause accidents, damage facilities, and disrupt traffic flow seemed more important. At this year's Fourth meeting, held in early March, the emphasis had clearly changed in 
order to address the new threat.

To make this point clear, Captain Andrew McGovern, Chairman of the Harbor Safety, Navigation, and Operations Committee of the Ports of New York and New Jersey, described the importance of the maritime community in easing the aftermath of the September 11 attacks. Because the attacks disrupted ground transportation, electric power, communications, and water in lower Manhattan, the maritime industry was called on to aid in rescue and cleanup operations. The maritime aspect of the operation used 20 Coast Guard cutters, 1200 Guardsmen and women, and 28 small boats, as well as numerous volunteer private craft. The North Cove Yacht Harbor became the base of operations for the rescue effort, and the maritime industry was basically in charge of that effort until Friday, the $14^{\text {th }}$. Because the water mains were broken, fireboats were used to extinguish most of the fires. Coast Guard vessels and port ferries escorted approximately one million persons off Manhattan Island. For about two weeks after the attack, communications came by use of the VHF radio systems of the vessels, because the attack disrupted most regular and cellular telephone communication. Virtually every VIP who visited "Ground Zero" in the first days after the attack arrived by boat. Vessels also provided support for the approximately 5000 relief workers, and transported almost all of the heavy construction/debris removal equipment to the site. ${ }^{2}$

Following the 9/11/01 incidents, the US Coast Guard began the enforcement of a broad range of security measures directed at all vessels calling on US ports. Almost immediately, the standard 24-hour "Advance Notice of Arrival" required for all vessels above 300 gross tons was changed to a 96-hour requirement. Previously exempted vessels, such as certain Canadian Great Lakes carriers and vessels operating on fixed schedules, now must meet the new standard, although some exemptions remain in effect. The vessel must also report more information regarding its particulars (i.e., owner, operator, classification society, port of origin, type of cargo, etc.). The new rules pay special attention to vessels carrying "certain dangerous cargoes," such as explosive materials, poison-inhalation hazard products, oxidizing materials, and a variety of other hazardous chemicals. Vessels departing US ports and carrying "certain dangerous cargo" must file an Advance Notice of Departure, under the same basic rules as the Arrival Notice.

The Coast Guard has also established a security zone around port infrastructure at every US port. Any commercial vessel that is to enter a security zone must undergo a screening process that includes a review of the crew and passenger lists (with nationalities of each person). The Coast Guard uses the vessel, crew, passenger, and cargo information to make a judgment as to any security measures that need to be taken for the particular vessel.

In addition to these port-infrastructure security zones, at every port where a US naval vessel lies at berth or where such a vessel plies navigable waters, the Coast Guard has established a 500-yard Protection Zone around each vessel. No-wake speed restrictions apply to all vessels within that distance from the naval vessel. Further, no nonmilitary vessel may approach within 100 yards of a US naval vessel, without authorization, regardless of whether the naval vessel is at berth or underway. A similar protection zone applies to submarines and aircraft nearing naval vessels. They are required to radio their intentions on a designated frequency as they approach the vessel. Related to these last two Coast Guard restrictions are numerous local restrictions in specific navigation areas that further regulate traffic around vessels and port facilities.

Another post-9/11 measure that is relevant to both vessel and port security is the Coast Guard's Sea Marshal program. Under this measure, the Coast Guard screens vessels to determine their perceived level of security risk - sort of a "vessel profiling" program. If the perception is that the level of risk is high, a team of (usually two to six) Sea Marshals will board the vessel (usually at the same time a pilot boards to bring the vessel into port). These teams carry weapons, and they have responsibility of securing the vessel's bridge and engine room so that no unauthorized person can take control of the vessel as it enters a port. ${ }^{3}$

Since containers are considered a major target of terrorists, US Customs and the Coast Guard, as well as individual US and world ports, are studying ways to make containers less vulnerable to terrorist activity. Currently,

${ }^{2}$ Capt. Andrew McGovern, "Responding to Terror-The Port of New York and New Jersey on September 11, 2001, speech given at Fourth National Harbor Safety Committee Conference, Galveston, Texas, March 3, 2002.

${ }^{3}$ Foss Marine Services, "New Security Measures," special supplement to Pacific Maritime magazine, January 2002. 
only about two percent of containers entering the US are inspected. It takes approximately five hours to physically inspect a typical container. Given the current manpower for inspection, if every container entering the US were to be inspected, it would take approximately one year to inspect them! Worldwide, there are approximately 125 million containers moving between countries each year.

Since cruise ships are the maritime counterpart of commercial airliners, the Coast Guard now escorts cruise ships into and out of ports, and the cruise lines submit their crew and passenger lists to various federal officials, such as the FBI and Immigration and Naturalization Services for security checks. It is obvious that a group of terrorists who board a cruise ship could create major destruction of port property and disruption of commerce and loss of life through destruction of the vessel if they were to seize control of it. It should also be obvious that not all of the same passenger screening rules that apply to air travel can apply here. For example, it is unlikely that cruise ship screeners will take away a passenger's nail file or manicure scissors. Therefore, the security rules must be flexible enough to apply to a variety of situations.

A question that has been raised but is left mostly unanswered is that of allowing guns on board a vessel. Should the crew of a cargo or passenger vessel be trained in the use of small arms, such as shotguns, handguns, or some form of automatic or semi-automatic weapon? The Coast Guard's answer, to this point, is that the problems with such a program are simply too onerous to allow it. Licensing requirements for US merchant mariners do not include weapons training. The training and licensing requirements would need to be lengthened and testing strengthened in order to arm a ship's crew. Further, numerous international, national, and local restrictions might make weapons unlawful in a particular port.

The American Association of Port Authorities (AAPA) and its member ports work with the Coast Guard, the US Customs Service, and other federal and state agencies to help promote port and vessel security. Among the key issues that the AAPA believes necessary to address the security problem are:

- $\quad$ A partnership approach among Federal, state, and local governments, seaports, and private industry, and including international partners at border ports;

- Increased funding for Federal agencies charged with protecting our Maritime Transportation System;

- Increased Federal funding for ports; currently, very little port infrastructure funding is federally providedmost is from local port authority funding;

- Local port security and safety committees; ports are not "cookie cutter" in their makeup; while standards must be developed, there must be some degree of local flexibility;

- $\quad$ Threat assessments with regard to a port or vessel's vulnerability to terrorism;

- Information sharing; enhancement of communication and cooperation between ports and security agencies;

- $\quad$ Seaport security program development and personnel training; certification of port security officers;

- Cargo controls and monitoring; international cooperation between countries over import and export cargoes; international exchange of crime and security information;

- $\quad$ Technology, research, and development; federal incentives for development and application of new security technologies; more funding for security equipment. ${ }^{4}$

The US Department of Transportation has recently approved a Port Security Grants program, administered by the Maritime Administration and the Coast Guard, on behalf of the Transportation Security Administration. By

${ }^{4}$ American Association of Port Authorities, “AAPA Policy Position on Seaport Security,” 2002. 
the end of June 2002, this program will make available $\$ 93.3$ million to port applicants for the purpose of "security assessments and mitigation strategies" that focus on technology improvements to provide safety and security for facilities, vessels, cargo, and passengers.

\section{Transportation and Trade-related Communications}

As previously mentioned, the 9/11 attack in New York City disrupted and/or overwhelmed several of the area's major forms of communication-standard and cellular telephones and, eventually, even the maritime VHF radio system, as well as the electrical grids that power most communications tools. Cyber-terrorism, destruction of power sources, and other forms of terrorism that disrupt communications can be a serious threat to commerce. The maritime industry must find new communications technologies and better apply old ones to make sure that a terrorist attack does not shut down international trade.

The sophisticated electrical and communications systems in wide use in developed nations create a doubleedged sword. By relying on complicated communications networks and by concentrating vital assets into small geographic areas, high-tech Western countries have placed themselves at a higher level of risk of disruption by a clever group of terrorists. By using such simple devices as helium balloons with long metallic tails and homemade mortars to fire them near a power substation, a small group of terrorists can shut down the electrical system of a large geographic area. Given the sharing of electricity, necessary to maintain our national power grid, a few such groups could create a massive set of power failures across a country, shutting down not only communications, but also water and sewer systems, traffic signals, and numerous other systems vital to our functioning as an economy. ${ }^{5}$

The second edge of the sword lies in the fact that terrorists, even in undeveloped countries such as Afghanistan, have ready access to many of the very same high-tech communications systems that they want to destroy in the West, and have used these systems to gather information through television and the Internet. They have then also used cellular telephones, computers, and other similar devices to plan and coordinate their attacks. Our inability to quickly capture Osama bin Laden and other al-Qaida leaders is at least partially due to their ready access to American news programs and to cell phone technology.

From a maritime industry perspective, effective communications is a fundamental aspect of vessel and port security. Many ports are now using a Vessel Tracking System (VTS) for commercial vessels that dispenses information about vessels as they come within certain port boundaries. San Francisco and Houston were the first ports in the US to apply such a system, but other ports are seeing the value of VTS for traffic control. It is becoming clear that, until advanced, web-based VTS systems are available, vessels should be equipped with transponders and/or other signaling devices similar to those used by aircraft. The ability to track a vessel long before it enters a port's waters provides an effective means of "pushing back the borders" by allowing the Coast Guard, US Customs, and other security personnel to "inspect" vessels outside of any danger zone to the port. Various countries are moving to equip all commercial vessels with transponders by 2007.

For safe and secure cargo, it is important to equip ports and US Customs officials with better technology to inspect all freight. Although containers carry a very large portion of high-value cargo in international trade, US Customs is only able to inspect about $2 \%$ of containers that pass through our ports and across our borders. More effective use of Global Positioning System (GPS) technology that allows for better tracking of containers and provides more information regarding origin and movement over a container's entire voyage would make containers safer in much the same way that verifying luggage and connecting it with its owner provides a positive control system for air travel.

Further, because the shipper seals containers at their loading point, they should remain secure as long as no one tampers with them in transit. At most ports, inspection requires the physical opening of a container to verify its contents - obviously a time-consuming process. Gamma X-ray and other technologies could eliminate the need for so much Customs inspection manpower, and could increase the proportion of containers inspected at every port. While it is unlikely that there will ever be a $100 \%$ inspection rate, increasing the likelihood of inspection should act

\footnotetext{
${ }^{5}$ Thomas Homer-Dixon, “The Rise of Complex Terrorism,” Foreign Policy, January/February 2002, pp. 52-53.
} 
as a deterrent to terrorist and other illegal activity related to containers. Currently, there are only 19 gamma X-ray machines operating at all US ports.

\section{Trade Levels}

Because of the downturn in economic activity in much of the world over the last couple of years, it is difficult to pinpoint the effects of $9 / 11 / 01$ on world trade. However, it is important to look at several trends that indicate with some degree of certainty that the attacks certainly have not done the world's economies any favors, at least in the short run. The long-run effect, however, might be a different story.

With regard to US trade levels, foreign imports declined 14\% in September 2001 from the August level, to $\$ 96$ billion. Service-sector imports were most severely affected-down $74 \%$, but goods imports also declined--by $3 \%$, to $\$ 91.5$ billion. Petroleum imports remained approximately level in volume, but decreasing prices caused a reduction in the total value of oil trade. The September decline, however, continued a trend that had occurred over the seven prior months. By principal end-use category, capital goods were the biggest import loser for the first three quarters of 2001, down 10.3\% over the January-September period from the previous year. Automobiles were also weak imports, declining $3.2 \%$.

US exports were also sharply lower, falling by $8.6 \%$ from August's level, to $\$ 77.3$ billion. The good news, if there was any, is that since imports fell by a greater value than did exports, the US balance of trade actually increased, reducing the monthly deficit to $\$ 18.7$ billion in September, down from $\$ 27.1$ billion in August. For the first three quarters of 2001, automobiles and capital goods were again the big losers, falling 7.4 and $5.4 \%$, respectively, compared the same period in $2000 .^{6}$

By November 2001, this downward trend was evident along the major US trade lanes for containerized freight, measured in TEUs. An examination of the five largest shipping lines ${ }^{7}$ in each of the seven major trade lanes ${ }^{8}$ shows, in comparison to November 2000, a decline in imports on five of the seven trade lanes and a decline in exports on six of the seven. Only Trans-Pacific export trade increased from the prior year, and that by only $0.9 \%$. Import trade increased only on the East Coast South America route, by a substantial 12.2\%, and Africa/Middle East trade remained mostly level, rising by $3.4 \% .^{9}$

Overall US waterborne containerized foreign trade (exports plus imports), valued in US dollars, was down over 8\%, from $\$ 62.7$ to $\$ 57.7$ billion, in September of 2001 compared to September 2000. However, for the first three quarters of 2001, the value of total trade remained relatively flat, declining by only $0.8 \%$. Cargo volume, in metric tons, was, again, down in September-by about $6 \%$, but was flat for the first three quarters, rising by $0.4 \% .^{10}$ By the end of the year, the effects of the $9 / 11$ attacks were visible but small, with overall US imports up 1.3 percent and exports down 2.8 percent compared to 2000 levels. ${ }^{11}$

A brief look at our major trading partner, Canada's, trade statistics shows that, similar to US trends, overall merchandise trade for the 2001 through October was virtually flat. Exports rose by $0.3 \%$, while imports fell by $1.9 \%$ from the previous 10-month period. ${ }^{12}$ Latin American trade has seen a downturn, but it is difficult to separate terrorist activity from other economic impacts, such as the financial problems and subsequent currency revaluation suffered by Argentina. In general, what seems to have occurred is a temporary increase in the rate of decline in economic activity that a number of countries had been seeing over the last two years, and then a leveling-off and smoothing-out period by the six-month anniversary of the WTC attack. Longer-term effects on Western nations remain to be seen, but all the evidence thus far seems to signal that the terrorists have not yet damaged trade signifi-

\footnotetext{
${ }^{6}$ American Association of Port Authorities, Advisory, December 3, 2001, p. 2.

${ }^{7}$ The shipping companies' importance varies among different trade lanes, so that the same five companies are not present in every lane.

${ }^{8}$ These are Trans-Atlantic, Trans-Pacific, East Coast South America, West Coast South America, Oceania, Central America/Caribbean, and Africa/Middle East.

9"PIERS Trade Monitor," JoC Week, February 4-10, 2002, p. 35.

${ }^{10}$ American Association of Port Authorities, Advisory, January 21, 2002, p. 1.

${ }^{11}$ JoC Week, February 25-March 3, 2002, p. 18.

${ }^{12}$ American Association of Port Authorities, Advisory, January 7, 2002, p. 5.
} 
cantly.

The new embargo by the US on 24 small countries who are suspected harborers of terrorists, however, may have much more severe consequences on their output and on their ability to trade unless they comply with US requirements to stop terrorism. These countries depend on imports and exports for a large portion of their GDP, which will be dramatically reduced unless they join the war against terrorism, and many of them have historically depended on trade with the US. It may be a terrible irony that countries that accept and promote terrorist activity will see their trade suffer much more than the countries they are trying to harm while, at the same time the new threat of terrorism forces the Western countries to spend even more on research and development of new technologies. The result of these actions most likely will be an even greater gap in wealth between the freer countries of the West and the politically and economically repressed nations who harbor the "evil doers."

\section{Marine Insurance}

\section{A. Introduction}

The effect of a terrorist act on any maritime vessel has major consequences for the individual company as well as the industry. If an American is killed while on a cruise, the potential is termination for the entire cruise industry. Since $95 \%$ of all world cargo is transported by water, a disruption in shipping has disastrous consequences for world trade. Terrorist acts especially affect liability insurance for ships and maritime freight rates.

\section{B. History and Background}

Marine insurance concepts are very different from the normal US insurance practices found in life, health, accident, auto, and property insurance, which are based on actuarial and statistical analysis of large samplings or groups. Marine insurance is a non-regulated, negotiated contract that varies from company to company and is based upon an underwriter's opinion of the worth or value of the shipping business to the insurance company and whether the policy will result in a profit or loss from the contract after claims are paid. Marine insurance policies have as many clauses as hospitals have Band-Aids and all of them affect the risk undertaken by the ship owner and the underwriter.

Thousands of years ago, the Code of Hammurabi provided rules governing trading relationships between the cargo owner and the vessel owner that have evolved over the centuries. ${ }^{13}$ Marine insurance is generally categorized either as hull, protection and indemnity (P\&I), or cargo insurance. The standard American Institute Hull policy, which covers physical damage to the ship's hull and equipment from fortuitous accidents that have a direct and proximate cause to the event includes four basic clauses: 1) Perils, 2) Additional (Inchmaree) Perils, 3) Deliberate Damage (Pollution Hazard), and 4) the Liner Negligence clause. ${ }^{14}$ The Hull insurance "running down clause" provides a form of liability collision protection for the vessel from collisions with other vessels, strandings, or groundings. ${ }^{15}$ General Average is a concept of marine insurance that affects imperiled property in the maritime adventure requiring voluntary sacrifices or extraordinary expenditures made for the sake of all with the resultant loss being made good by the contribution of all whose property is saved. ${ }^{16}$ P\&I insurance is the major liability insurance protecting loss of life, injury, cargo damage, and even fines and penalties. ${ }^{17}$ Cargo insurance has no standard form, but instead consists of only a few agreed-upon clauses that cover the interests of shippers of the cargo, the vessel owners, and the underwriters who act in Uberrimae Fidei-utmost good faith with each other.

All cargo shippers desire to know the extent of liability of the vessel owner for loss or damage to the cargo. In the United States, the Carriage of Goods by Sea Act (COGSA), 46 USC 1300, regulates the shipment of goods by common carrier by establishing a minimum liability of $\$ 500$ per package. ${ }^{18}$ In 1921 , an international conference was

\footnotetext{
${ }^{13}$ Arthur L. Flitner, Arthur E. Brunck, Victor P. Simone, and C. Arthur Williams, Ocean Marine Insurance, $2^{\text {nd }}$ Edition, 1992, Volume 1, p. 2.

${ }^{14}$ Flitner, Brunck, et al., pp. 153-165.

${ }^{15}$ Flitner, Brunck, et al., p. 177.

${ }^{16}$ Flitner, Brunck, et al., p. 37.

${ }^{17}$ Flitner, Brunck, et al., p. 27.

${ }^{18}$ Flitner, Brunck, et al., p. 69.
} 
held in The Hague, Netherlands, for creating uniformity in ocean bills of lading; however, COGSA does not apply to private charter parties. The evolution of these principles and laws results in a compromise between the shipper and the vessel owner. To hold the ship owner liable, proof must be sufficient to show a failure of due diligence in maintaining the vessel in a seaworthy condition. This test of reasonableness is a question of fact determined by the evidence, by looking at what was done versus what could have been done. The ship owner has seventeen defenses that exempt him from liability.

\section{War Risk Insurance Rates and Coverage}

In the United Kingdom, the war risk clause is an endorsement to the insurance policy. In the US, war risk is a separate policy. Either way, the underwriter has the right to cancel the insurance upon seven days notice. This action enables the underwriter to reassess the policy and to charge an additional premium for vessels trading in a "zone" where hostilities or war might occur.

The 9/11 events caused underwriters who had never contemplated these terroristic events to re-write the war risk insurance policy because the hull policy does not exclude terrorism. Before this disaster, underwriters were losing money on insurance premiums; notwithstanding, the increases in premiums are inadequate to return the underwriters' profitability to former levels. On March 8, 2002, Lars Gustafson, Vice-president and insurance broker with Marsh \& McLennan Brokerage of New York City, related that all marine policies would experience a 20 to 30 percent increase in premiums. Although ship owners might desire to forgo the coverage of the war risk policy, their lenders will require that ship owners maintain the policy as a condition of the vessel's mortgage. ${ }^{19}$

As a reaction to the US declaring war on terrorism, the underwriters of the Lloyds' London Market demanded huge increases in war insurance premiums. War risk underwriters are seeking additional single-voyage premiums (equal to about $0.25-0.30 \%$ of the combined value of the cargo and the vessel) for tankers trading in the Persian Gulf. ${ }^{20}$ The cost of sending a containership through the Suez Canal or a tanker to a loading terminal in the Persian Gulf will now be quite high. A mere two days after the catastrophe in New York City, underwriters required these additional premiums for vessels sailing to newly excluded areas such as the Persian Gulf, the Red Sea, Pakistan, and Egypt. In the aftermath of 9/11, re-insurance companies have been suspending insurance coverage for terrorist events in the United States, and several primary insurers are planning to withdraw from the market. Since the US Congress began debating the possibility of federal insurance for terrorist risks, there has been virtually no media or industry discussion of the precedents for insuring maritime risk during wartime. ${ }^{21}$

The typical charter party from ASBATIME or BIMCO permits the Protection and Indemnity Mutual Club that provides insurance to the ship owner for normal risks to automatically cancel the policy in the event a ship travels into a war zone. To overcome the potential breach of warranty, the ship owner immediately notifies the time charterer or cargo shipper that the daily hire rate will immediately increase to pay for this unforeseen event. In the event that the charterer does not agree to the increase, the ship owner will terminate the charter party and order the Master of the ship to steer to the nearest available port, where the cargoes are placed into protective storage until the dispute is resolved.

Lloyds' underwriters of London--the dominant war risk insurance company--has adopted a 48/7 policy; the 48-hour quote covers only a seven-day voyage into an excluded area. ${ }^{22}$ If the ship owner wishes to reject the coverage, the action must be within 48 hours or he will be charged for the coverage. By increasing annual war risk premiums (by between 400 and 500\%) and by imposing costly additional premiums to reinstate coverage for trading in excluded areas, underwriters force the ship owners into very difficult financial and, consequently, legally disputed situations $^{23}$. For a relatively low-valued modern $\$ 10$-million general cargo ship, these additional costs translate into an increase in its annual war risk premium to $\$ 5,000$, from its usual $\$ 1000$. A large double-hulled tanker insured for

\footnotetext{
${ }^{19}$ Lars Gustafson, conversation with H.G. Van Dell, at Marsh \& McLennan Brokerage, New York, NY, March 8, 2002.

${ }^{20} \mathrm{http}: / / \mathrm{www}$. tradewinds.no/daily/news/article/2001/09/12/004715.html. These market rates are quoted for al-Bakr in southern Iraq.

${ }^{21}$ David Hale, "Insuring a Nightmare." March/April, 2002, http://www.worldlink.co.uk/stories/storyReader\$1075

${ }^{22} \mathrm{http}$ ://www.tradewinds.no/daily/news/article/2001/09/18/004778.html

${ }^{23} \mathrm{http}: / /$ www.tradewinds.no/daily/news/article/2001/09/12/004715.html
} 
$\$ 100$ million and normally paying $\$ 10,000$ for its annual war risk coverage, will now pay $\$ 50,000$. The rate hikes for the latest, state-of-the-art, cruise ships are even greater, with vessels that had been paying $\$ 40,000$ now facing $\$ 200,000$ premiums. ${ }^{24}$ Voyage premiums have skyrocketed due to America's war on terrorism. The government of India imposes increased rates on war risk coverage. Since the war on terrorism, ships costing $\$ 15$ million that ply Indian waters must pay $\$ 75,000$ above the basic $\$ 120,000$ premium in order to enter an excluded zone such as the Suez Canal. Indian basic maritime insurance rates are often as high as four times the international rates. The ASEAN Shipowners Association has seen rates increase from .005 per cent of a ship's total value to about .05 per cent, so that ship owners' insurance costs have increased to about ten times their pre-9/11 levels. ${ }^{25}$ Because of greater war risks for vessels plying the Persian Gulf, shipping rates are expected to rise by an average of 10 to 15 percent. London underwriters have already announced that they will increase war-risk rates for "hull and machinery coverage," and experts project that they will soon double--to 0.025 percent of a vessel's value. ${ }^{26}$

Although the very high rates and broad zones of exclusion from coverage will likely diminish over time, the increased premiums will continue for many years. The cyclical nature of insurance is swinging in favor of the underwriter. Unfortunately, some vessel owners have been forced to sell some of their ships in order to pay for increased operating costs in their remaining fleet. ${ }^{27}$

Since the war on terrorism began, a number of angry Pakistani businessmen have denounced the war surcharge as an attempt at blackmail, amid claims that Pakistani waters are open for unfettered shipping and free trade. Unfortunately, they misunderstand the concept of war risk coverage. A war zone is any area in which hostile or military activities occur; it is immaterial that Pakistan has attacked no one. By collecting a premium of $\$ 300$ per 40 foot container, however, shipping agents have created a loss of $\$ 35$ billion for Pakistan. ${ }^{28}$ Egypt suffers a similar situation. The increase in insurance premiums has caused the Ministry of Economy there to project a $\$ 140$ million loss for the country. Last year, the tourism industry generated $\$ 4.3$ billion; however, the forecast for 2002 is a drop of $35 \% .{ }^{29}$

The US insurance industry does not have a means to exclude terrorist actions for firms providing workers' compensation coverage (although state insurance laws require such coverage). Congress has so far failed to pass legislation that would offer reinsurance coverage above levels that would limit catastrophic losses to insurance companies. Consequently, businesses must accept increases in premiums averaging between 50\% and 100\% of pre-9/11 rates. Yet, even with these exorbitant premiums, coverage is hard to find. Reinsurers have excluded the coverage even though individual state-licensed insurance companies must offer the coverage. The obvious analogy is the recent dilemma confronting local electrical utilities (such as Pacific Gas \& Electric) in California who were trying to buy wattage when local rates were fixed while, during the same period, wholesale rates fluctuated (and, in particular, rose). Marine insurance companies do not have this problem, however, since all policies have very-limited-time coverage ( 7 days) and limited areas or global zones for application with very quick cancellation provisions. ${ }^{30}$

The terrorist attacks of 9/11 caused billions of dollars worth of damage to third parties. Previously, insurance companies thought that terrorist attacks by commercial aircraft were very unlikely; therefore, they handily provided insurance to cover such events. After $9 / 11$, when insurers terminated ready coverage of such events, they instead offered, say, $\$ 50$ million per event, an amount that the airlines considered woefully inadequate, so they refused to fly without sufficient insurance. Most governments of North America and Europe, however, have agreed to look at the possibility of temporary re-insurance. Two of the proposals being considered are "Equitime," organized by the Marsh Company, and American International Group's (AIG) proposal. Equitime is less expensive (capitalized at $\$ 300 \mathrm{M})$ and offers coverage to $\$ 1.5 \mathrm{~B}$, but requires the government to act as re-insurer. AIG's insurance stops at $\$ 1 \mathrm{~B}$, but does not require government guarantees. AIG contends that adequate insurance is available in the private

\footnotetext{
${ }^{24} \mathrm{http}: / /$ www.tradewinds.no/daily/news/article/2001/09/17/004763.html

${ }^{25} \mathrm{http} / / / \mathrm{www}$. ilo.org/public/english/dialogue/sector/papers/factsheet/sep11_mariti.htm\#moreinformation

26،"On-Line-Steamship Lines," The American Journal of Transportation. http:// www.ajot.com, November 30, 2001.

${ }^{27}$ Lars Gustafson, conversation with H.G. Van Dell, at Marsh \& McLennan Brokerage, New York, NY, March 8, 2002.

28“"Imposition of War-Risk Surcharge Unjustified." Business. http://www.DAWN.com, November 19, 2001.

${ }^{29}$ Adam Morrow, “Arab Economies Before And After 11 September." http://www.arabfinance.com/AFSource/AFSource.asp?C=14\&D=0, January 9,2002

30“"The Workers' Compensation Dilemma," http://www.standardandpoors.com/Forum/RatingsCommentaries/Insurance/
} 
sector without government intervention. The European countries are debating coverage up to $\$ 5 \mathrm{~B}$ with government guarantees. Regardless of the final policy, the enormity of third party collateral damage from terrorist attacks will surely affect the manner by which transportation business is conducted, and will ultimately result in higher costs to the service provider and to the consumer. ${ }^{31}$

\section{Maritime Freight Rates and Industry Reactions}

The attacks on the World Trade Center and the Pentagon illustrate how interrelated the global economy has become over the past few decades. Short-term growth forecasts have been reduced, and the International Monetary Fund's World Economic Outlook has reduced its forecasts for world economic growth from 3.9 per cent to 3.5 per cent for 2002. ${ }^{32}$

Reductions in maritime freight rates over the last several months illustrate the dysfunctional nature of container vessel ship owners and of the ports that encourage mega vessels. In 1975, the volume of containerization was one million TEUs; by 2001 the volume had risen to over 125 million TEUs. ${ }^{33}$ Even before 9/11, container trade needed to grow by $25 \%$ in 2002 and by $10 \%$ in 2003 to justify the increase in new buildings of mega containerships. To maintain a proper balance between shipping capacity and freight demand, vessel owners need to scrap about 600,000 TEUs of existing (but old and inefficient, and lower end of the class) post-Panamax vessels. ${ }^{34}$

Approximately eleven million deadweight tons of new containerships will be constructed in the next two years, which will represent a thirty-percent increase in world container fleet capacity. However, demand for container carriage will grow only by approximately six percent per year. Since Western nations subsidize both shipping and shipbuilding for political reasons and national security issues, the US and other governments oppose or, at the least, clearly do not encourage the vessel scrap industry. The argument is that, without subsidies, US lines will reflag their ships to hire cheaper crews and that American-flagged vessels will be unavailable to transport US troops in emergencies, causing a reduction in US defense capabilities. ${ }^{35}$

"We have subsidies, loan guarantees, preference cargoes, cabotage laws, and antitrust immunity to fix prices, yet we lose money! That's not easy to do, but it seems to be one thing at which we excel." ${ }^{36}$ Shipowners for years have had difficulty making a profit. The transportation freight charge for moving a container from Hong Kong to Hamburg is less than $\$ 500$. To compensate for low profits in recent years, the world's largest shipping companies, such as Maersk, APL, and OOCL, have opted for increasing vessel size to the 'super-Panamax' ship capable for carrying 6,000 or more TEUs. Consideration is being given to building 12,000-TEU vessels that would allow carriers to take advantage of density and scope economies by reducing crew and fuel used per container. To accommodate such a ship any port must have a channel and wharf side depth of over 55 feet deep. A number of ports in the US, as well as Le Havre, Rotterdam, Antwerp, Amsterdam, Hamburg and Southampton are investing (wasting?) money and creating (perhaps redundant) infrastructure out of fears that their port will become obsolete. Loading or discharging 12,000 TEUs can tie up the entire port's container infrastructure and would require a line of trucks stretching a distance equal to that of, say, New York City to Washington D.C. Most existing gantry cranes are much too small to reach across the beam of these ships. A glance at the close proximity of several of these ports shows the foolishness of the spending; Le Havre is across the English Channel from Southampton, and is only about 250 miles from Amsterdam, which is only 300 miles from Hamburg. The ports fear that not competing will cost them millions of dollars in lost handling and storage fees. Further, the loss of traffic reduces the ports' hinterland influence and causes a number of businesses to find other locations that are more attractive. APL moved its postPanamax vessels from Oakland, California, and Hanjin moved from Portland, Oregon, to Vancouver, British Columbia. Eventually, these mega containerships will dock at only a small group of mega ports, such as Singapore and

\footnotetext{
31"Governments are under pressure to remain insurers of last resort," Economist.com, March 29, 2002,

http://www.economist.co.uk/finance/displayStory.cfm? Story_id=1050061

${ }^{32} \mathrm{http}: / / \mathrm{www} . \mathrm{imf}$. org/external/pubs/ft/weo/2001/02/index.htm

${ }^{33}$ Jane de Gerlund, Ed. Containerisation International Yearbook 2001. Great Britain: Blackbear Press, Ltd., 2001, pp. 8-11.

34،"Excess Capacity Worries the Shipping Industry," Malaysian Maritime Cyber Hub, http://www.portsworld.com.

${ }^{35}$ Alasdair Forbes and Tom Price, "Heading for Troubled Waters," AB, April 1, 1996.

${ }^{36}$ Conrad H.C. Everhard, "Big ships, little plans plague Industry," American Journal of Transportation On-Line - Industry Opinions.com.
} 
Rotterdam. ${ }^{37}$

The worldwide economic slowdown that was exacerbated by the events of 9/11 has caused the demand for containerized transport to continue its decline, and freight rates are reflecting the decreased demand. Outbound freight rates for agricultural products and other dry container cargoes and rates for westbound transpacific cargoes have suffered the most, with rates approaching historically low levels. ${ }^{38}$

The Global Alliance (or Grand Alliance) is a cartel (granted immunity from antitrust laws) composed of OOCL, APL, P\&O Nedlloyd, Malaysian International Shipping Corporation, and Mitsui OSK lines. This cartel offers the cargo shipper many sailings per week and the full logistics service of multi-modal door-to-door connections using ships, barges, trucks, and trains. The creation of such alliances has resulted in consolidation in the market, with the smaller players disappearing. Because of barriers to entry created by government protection and the enormous level of capitalization required, cartels such as the Global Alliance should be able to use their market power to drive freight rates back to higher levels but, at this writing, rates remain low.

The current buyer's market creates financial problems for small shippers. The projection is that North Atlantic carriers will lose $\$ 600$ million in 2002. For example, the daily charter rate for a 2,000 TEU ship has declined 34 percent from its 2001 rate of $\$ 16,396$ to $\$ 10,858$ as of this writing. A ten-year old 1700-TEU containership has fallen in value from $\$ 15.5$ million to $\$ 10.5$ million in one year. The Journal of Commerce reported that freight rates rose $3 \%$ in the first quarter of 2001 , but declined $8 \%$ in the last three quarters. The current feeling among shippers is, "cash is king, but cargo is the emperor." 39

The terrorist attacks may have had their greatest effect upon the cruise industry. Since 9/11, both Renaissance Cruises--the world's fifth largest cruise line--and American Classic Voyages have filed for bankruptcy, and P\&O Princess Cruises and Royal Caribbean Cruises have agreed to merge. America's last passenger cruise line, American Classic Voyages of Hawaii, recently completed its bankruptcy with the transfer of its vessel MS Patriot to Holland American Line for $\$ 79.8$ million. ${ }^{40}$ These mergers and bankruptcies have cost several thousand workers at these companies their jobs. Travel sections in most newspapers are now offering large discounts for cruises-- $\$ 300$ provides a passenger with a five-day cruise from Galveston, Texas, to Cancun. Immediately after 9/11, fearful passengers cancelled trips by the score. P\&O Princess Cruises cancelled a 71-day world tour because it included stops in the Middle East. Royal Caribbean reported that cancellations were $43 \%$ higher than during the same period in 2000. Carnival Cruise Lines is slashing cabin prices to attempt to allay passenger fears and is also now offering two-for-one specials. Walmart.com is offering a special three-day "Bahamas Getaway" for \$247. ${ }^{41}$

\section{Conclusions}

The events of 9/11/2001 were conducted not only to destroy a few buildings and kill innocent Americans, but primarily to introduce us to "weapons of mass disruption" that would destroy our way of life through market disturbances. While the greatest publicity in the 9/11 aftermath has been associated with passenger air travel security, terrorism creates a far greater threat to maritime shipping because of the potential disruption, and even shutdown, of world trade that such an attack would cause.

One result of the 9/11 events has been an immediate response by the US Coast Guard to provide greater security around ports and on vessels, and the global maritime community is responding in like fashion by beginning a research and development effort to find more effective ways to secure port and vessel infrastructure. One area where improvements will be made in the near future is that of vessel communication. Transponders will be mandatory on vessels, and improved vessel tracking systems will be installed at many ports.

\footnotetext{
${ }^{37}$ Bruce Barnard, "Is it a Boom-and-Bust Market for Boxes?" JoC Gulf Shipper, January 28, 2002.

${ }^{38}$ US Department of Agriculture, "Agricultural Ocean Transportation Trends,"

http://www.ams.usda.gov/tmd/AgOTT/December\%202001/Dec2001_content.htm, December, 2001.

${ }^{39}$ Chris Dupin, “A Buyer's Market: Container ship charter rates are expected to remain low into 2002," JoC Week, November 26 - December 2 , 2001, page 12. JoC Week, February 18 -24, 2002, page 17.

${ }^{40} \mathrm{http} / / / \mathrm{www}$. travelscene.com.au/t034-marcruis.html.

41،"Carnival sets reservations record," http://www.marinelog.com. January 16, 2002
} 
The International Maritime Organization (IMO), cajoled by the might and will of the United States, has renamed a division of one of its subcommittees. The "Navigation Section of the Maritime Safety Division" (MSD) has been re-designated as the "Navigational Safety and Maritime Security Section." The IMO will create an International Code for the Security of Ships and Port Facilities requiring that every vessel designate a Ship Security Officer (another duty for the $3^{\text {rd }}$ Mate), who must train under the international convention that established the Standards for Training, Certification and Watch keeping (STCW). Someone ashore must be designated as "Company Security Officer," with training requirements and hopefully his own hat, with a badge. ${ }^{42}$ The ship owner's implied warranty of seaworthiness will include extra training in the areas of security and protection from terrorists' acts.

While the attacks had an immediate negative effect on world maritime trade, that effect appears to have been brief, and trade had already rebounded by the end of 2001. That, of course, is the good news, but the bad news is that the potential for a major disruption still exists, particularly if terrorists can destroy a port, a cargo vessel, or a cruise ship, or transfer a lethal biological or chemical agent via a waterborne vessel.

Most economists abhor the entrance of the government into the insurance industry, arguing that government inefficiency will raise rates and provide poorer coverage than private would insurers. But, unless the government passes laws that protect air and marine carriers from the possibility of huge terrorist-induced liabilities, it appears doubtful that the private insurance industry can provide coverage in the $\$ 20$ billion range now deemed necessary for operation. A better procedure would be to leave liability issues and amounts of coverage to those seeking the protection and simply require the insurance industry to offer insurance coverage, charging the premium needed to cover the exposure. Such a temporary government action would allow the marketplace sufficient time to reassess the risks and assign a fee to compensate for the coverage. As serious as the new threat of terrorism is, it will not kill the industry, but it will increase carrier costs a little (perhaps a lot for insurance). Security will continuously increase and improve for vessels operated by the industrialized nations; the ship owners from the developing nations will face difficulties from the new compliance training requirements.

Because of the terrorist attacks, one change expected in maritime shipping is the reflagging of some ships away from their flags of convenience to the flags of the industrialized nations. A reflagging would require ship owners to hire a crew belonging to that state's nationality, which would mean that Croatian, Philippine, Polish, Chinese, and other similar low-wage sailors would be replaced by more expensive American, British, Danish, Greek, German, or Norwegian officers and crew. The ship owner and cargo charterer would have to adapt to higher manning, vessel, and other logistical costs. It was expected that some US ship owners would reflag their vessels American and that many foreign vessels calling US ports would feel it necessary to do the same. The reflagging would have long-term positive effects on the size of the US merchant fleet and on the number of US merchant marines and would provide a more secure waterborne fleet in times of war. So far, however, markets are prevailing over security issues. Since insurance and other operating costs are rising, only a handful of ships have been reflagged because ship owners simply cannot afford the additional costs that crew and other requirements of the reflagging would entail.

The effect of increased training requirements, additional insurance premiums and possible changes in the nationality of crews will cause an increase in the costs of waterborne shipping. Most of these increases will be passed to the cargo owner who will, in turn, pass many of these costs to the consumer. Smaller companies that cannot take advantage of scale economies and a company of any size that does not take advantage of density and scope economies will disappear, leaving greater consolidation in maritime shipping. Unlikely as it seems, the typical ship owner will continue to not make a profit by shipping cargo, but will continue to stay in business by profitably exchanging vessels or providing additional services to the cargo shipper and manufacturer through increased coordination and communication.

Currently, the best bargain in sailing for the consumer is a short cruise. Since cruise lines need full ships to take advantage of scope and density economies, they are offering low rates. No tourist location offers $\$ 60$ per day for room, board, and entertainment, yet cruises from Galveston to Cozumel or Miami to the Virgin Islands offer a

\footnotetext{
42،“Opinion: IMO Increasing Ship Owner's Burden,” Shipping News, http:// www.marinelog.com. February $21,2002$.
} 
vacation for a family at per-person prices in that range.

While the events of 9/11/2001 have created some changes in the maritime shipping market, the market has simply responded by adjusting to those events. While the threat continues to affect insurance and has lowered carrier profits in the short run, the main result of the attacks that is very clear in the maritime industry is that members of the global maritime community are uniting together to enhance security in order to protect and preserve this very important market.

\section{References}

1. American Association of Port Authorities, "AAPA Policy Position on Seaport Security."

2. American Association of Port Authorities, Advisory, December 3, 2001, p. 2.

3. American Association of Port Authorities, Advisory, January 21, 2002, p. 1.

4. American Association of Port Authorities, Advisory, January 7, 2002, p. 5.

5. Barnard, Bruce. "Is it a Boom-and-Bust Market for Boxes?" JoC Gulf Shipper. January 28, 2002

6. "Carnival sets reservations record.” Shipping News. http://www.marinelog.com. January 16, 2002.

7. de Gerlund, Jane, ed. Containerisation International Yearbook 2001. Great Britain: Blackbear Press, Ltd., 2001, pp. 8-11.

8. Dupin, Chris. “A Buyer's Market: Container Ship Charter Rates are expected to Remain Low into 2002.” JoC Week, November 26 - December 2, 2001, page 12.

9. $\quad$ Everhard, Conrad H.C. "Big ships, Little Plans Plague Industry.” American Journal of Transportation On-Line - Industry Opinions.com.

10. "Excess Capacity Worries the Shipping Industry," Malaysian Maritime Cyber Hub, www.portsworld.com.

11. Flitner, Arthur L., Arthur C. Brunck, Victor P. Simone, and C. Arthur Williams. Ocean Marine Insurance, $2^{\text {nd }}$ Edition, Vol. 1. New York: American Institute, 1992.

12. Forbes, Alasdair, and Tom Price, "Heading for Troubled Waters," AB, April 1, 1996.

13. Foss Marine Services, "New Security Measures," special supplement to Pacific Maritime magazine, January 2002.

14. "Governments are under pressure to remain insurers of last resort," Economist.com, March 29, 2002, http://www.economist.co.uk/finance/displayStory.cfm? Story_id=1050061

15. Gustafson, Lars. Conversation with H.G. Van Dell, at Marsh \& McLennan Brokerage, New York, NY, March 8, 2002.

16. Hale, David. "Insuring a Nightmare." March/April, 2002.

17. Homer-Dixon, Thomas. "The Rise of Complex Terrorism," Foreign Policy, January/February 2002, pp. 52-53.

18. http://www.ams.usda.gov/tmd/AgOTT/December\%202001/Dec2001_content.htm, December 2001.

19. http://www.cmc-ccm.com/shipping.php?choice $=235$

20. http://www.ilo.org/public/english/dialogue/sector/papers/factsheet/sep11_mariti.htm\#moreinformation

21. http://www.imf.org/external/pubs/ft/weo/2001/02/index.htm

22. http://www.standardandpoors.com/Forum/RatingsCommentaries/Insurance/

23. http://www.tradewinds.no/daily/news/article/2001/09/12/004715.html

24. http://www.tradewinds.no/daily/news/article/2001/09/18/004778.html

25. http://www.tradewinds.no/daily/news/article/2001/09/17/004763.html

26. http://www.travelscene.com.au/t034-marcruis.html

27. http://www.worldlink.co.uk/stories/storyReader $\$ 1075$

28.

29.

30.

"Imposition of War-Risk Surcharge Unjustified." Business. http://www.DAWN.com, November 19, 2001.

JoC Week. February 25-March 3, 2002, p. 18.

McGovern, Capt. Andrew. "Responding to Terror-The Port of New York and New Jersey on September 11, 2001, speech given at Fourth National Harbor Safety Committee Conference, Galveston, Texas, March 3, 2002.

31. Morrow,Adam."Arab Economies Before and After 11 September." http://www.arabfinance.com/AFSource/AFSource.asp?C=14\&D=0, January 9, 2002

32. "On-Line-Steamship Lines," The American Journal of Transportation. http://www.ajot.com, November 30, 2001.

33. "Opinion: IMO Increasing Ship Owner's Burden,” Shipping News, http://www.marinelog.com, February 21, 2002.

34. "PIERS Trade Monitor," JoC Week, February 4-10, 2002, p. 35.

35. "The Workers' Compensation Dilemma." http://www.arabfinance.com/AFSource/AFSource.asp?C=14\&D=0, January 9, 2002.

36. US Coast Guard Office of Waterways Management Policy and Planning (G-MWP), MTS: Marine Transportation System information pamphlet.

37. US Department of Agriculture, "Agricultural Ocean Transportation Trends,"

http://www.ams.usda.gov/tmd/AgOTT/December\%202001/Dec2001_content.htm, December, 2001 